University of Nebraska - Lincoln

DigitalCommons@University of Nebraska - Lincoln

USDA National Wildlife Research Center - Staff Publications
U.S. Department of Agriculture: Animal and Plant Health Inspection Service

October 1995

\title{
BLACK BEAR DAMAGE TO LODGEPOLE PINE IN CENTRAL OREGON
}

Victor G. Barnes Jr.

USDI/NBS Kodiak National Wildlife Refuge

Richard M. Engeman

USDA/APHIS/ADC Denver Wildlife Research Center, s_r100@yahoo.com

Follow this and additional works at: https://digitalcommons.unl.edu/icwdm_usdanwrc

Part of the Environmental Sciences Commons

Barnes, Victor G. Jr. and Engeman, Richard M., "BLACK BEAR DAMAGE TO LODGEPOLE PINE IN CENTRAL OREGON" (1995). USDA National Wildlife Research Center - Staff Publications. 189.

https://digitalcommons.unl.edu/icwdm_usdanwrc/189

This Article is brought to you for free and open access by the U.S. Department of Agriculture: Animal and Plant Health Inspection Service at DigitalCommons@University of Nebraska - Lincoln. It has been accepted for inclusion in USDA National Wildlife Research Center - Staff Publications by an authorized administrator of DigitalCommons@University of Nebraska - Lincoln. 


\title{
BLACK BEAR DAMAGE TO LODGEPOLE PINE IN CENTRAL OREGON
}

\author{
VICTOR G. BARNES, JR. \\ USDI/NBS Kodiak National Wildlife Refuge, 1390 Buskin River Road, \\ Kodiak, Alaska 99503 USA
}

RICHARD M. ENGEMAN

USDA/APHIS/ADC Denver Wildlife Research Center, P.O. Box 25266, Bldg. 16, Denver Federal Center, Denver, Colorado 80225-0266 USA

\begin{abstract}
Black bear (Ursus americanus) damage to 108 lodgepole pine (Pinus contorta) trees was found in a mixed conifer habitat in central Oregon. No trees of three other conifer species were injured. Eighty-nine percent of the damage occurred in the same year. Nearly $20 \%$ of the freshly damaged trees had bark removed from more than $75 \%$ of the circumference and, judging from the fate of trees damaged in prior years, probably succumbed.
\end{abstract}

Black bears (Ursus americanus) feed on the sapwood of a number of species of coniferous trees and, in some habitats, have shown a definite preference for certain species. In western Washington and Oregon, Douglas-fir (Pseudotsuga menziesii) is reported to be selected more frequently than other species (Levin 1954, Childs and Worthington 1955, Hartwell 1973). In northwest California, extensive damage has been observed on redwood (Sequoia sempervirens) (Glover 1955). Additional reports indicate a preference for white spruce (Picea glauca) on the Kenai Peninsula in Alaska (Lutz 1951), western white pine (Pinus monticola) in interior British Columbia (Molnar and McMinn 1960), balsam fir (Abies balsamea) in Maine (Zeedyk 1957), Engelmann spruce (Picea engelmannii) in Yellowstone Park (Contor 1957), and subalpine fir (A. lasiocarpa) and whitebark pine (Pinus albicaulis) in Montana (Tisch 1961). Elsewhere in Montana $U$. americanus selected for western larch (Larix occidentalis), lodgepole pine (Pinus contorta) and P. engelmannii (Mason and Adams 1989).

Sapwood feeding by $U$. americanus has been observed in stands of $P$. contorta in Montana (Jonkel and Cowan 1971, Mason and Adams 1989), and in eastern Washington (Poelker and Hartwell 1973). Here, we describe evidence of exclusive feeding on $P$. contorta by $U$. americanus in a mixed conifer habitat in central Oregon.

\section{METHODS}

Observations reported here were made at about $1525 \mathrm{~m}$ elevation on the east slope of the Cascade Range and approximately $26 \mathrm{~km}$ west of Sisters, Oregon. The study area was classed in the P. contorta/ sedge (Carex pensylvanica)-lupine (Lupinus argenteus)-penstemon (Penstemon euglaucus) plant community (Volland 1976). The site was occupied by a seral community that resulted from a wildfire in 1930 . The over story was composed of $P$. contorta and $P$. ponderosa, lesser amounts of $A$. lasiocarpa, and occasional grand fir (A. grandis) and mountain hemlock (Tsuga mertensiana). There were scattered amounts of manzanita (Arctostaphylos patula) and snowbrush (Ceanothus velutinus). Representative ground vegetation in openings and under partial forest canopy included C. pensylvanica, mountain brome (Bromus carinatus), and $L$. argenteus. Forest cover was generally open as a consequence of interspersed natural openings and recent $(<3 \mathrm{yr})$ pre-commercial thinning. Site productivity was rated high for $P$. contorta, with an estimated growth index of $78 \mathrm{ft}^{3} / \mathrm{yr}$ (Volland 1976).

Damaged trees located in the course of other studies served as centers for intensive searches for additional trees damaged by bears. A search was conducted from each damaged tree, or patch of trees, in each of the cardinal directions up to $500 \mathrm{~m}$. Each newly identified damage site served as a center for further searches in the same fashion. Species, diameter at breast height (d.b.h.), and maximum height of stripped bark from ground line were recorded for each damaged tree. To classify degree of injury, the average extent of bark removal around the circumference of the main stem was estimated and assigned 
TABLE 1. Summarized data for 108 Pinus contorta trees damaged by Ursus americanus.

\begin{tabular}{|c|c|c|c|c|c|c|c|c|}
\hline & \multicolumn{4}{|c|}{ Freshly damaged trees } & \multicolumn{4}{|c|}{ Trees damaged in prior years } \\
\hline & $N$ & Mean & SD & Range & $N$ & Mean & SD & Range \\
\hline Age (years) & 36 & 34.6 & 11.7 & $19-75$ & - & - & - & - \\
\hline D.b.h. $(\mathrm{cm})$ & 96 & 24.4 & 6.4 & $12.7-44.5$ & 12 & 22.9 & 5.1 & $5.8-13.4$ \\
\hline $\begin{array}{l}\text { Height of barking } \\
\text { from base }(\mathrm{cm})\end{array}$ & 96 & 130.8 & 45.7 & $45.5-228.6$ & 12 & 139.7 & 9.4 & $94.0-188.0$ \\
\hline
\end{tabular}

to one of the following percent categories: 0-25, 26$50,51-75,76-100$. Fresh damage was readily distinguished from trees damaged in previous years because it was characterized by sharp, distinct grooves from the teeth, little solidified resin, and no thickening of the bark at the edge of the wound. Increment cores were extracted from 36 freshly damaged trees and processed for age and growth measurements. Two-sample $t$-tests were used to compare tree size and height of damage between freshly damaged trees and trees damaged in previous years.

\section{RESULTS}

We located and measured 108 bear-stripped trees, $96(89 \%)$ of which had fresh (same year) injuries (Table 1). None of the trees showed scars from feeding during more than one year. Seventy-seven percent of the bark-stripped trees were concentrated in two areas approximately 0.8 and 1.4 ha in size and $0.67 \mathrm{~km}$ apart. The maximum concentration was 49 stripped trees in slightly less than $0.6 \mathrm{ha}$, which represented about $20 \%$ of the pole-sized ( 13 to $38 \mathrm{~cm}$ d.b.h.) timber in that stand.

All 108 trees were $P$. contorta, indicating a preference for that species. Pole-sized $P$. ponderosa and $A$. lasiocarpa were available in the stands where feeding occurred and frequently were less than $3 \mathrm{~m}$ from a bark damaged tree. A. grandis or T. mertensiana occurring in the vicinity of stripped trees were less than $8 \mathrm{~cm}$ d.b.h., and may not have been comparable to $P$. contorta for preference.

Injuries ranged from a small wound of $<65$

TABLE 2. Classification of injuries inflicted by $U r$ sus americanus on 108 Pinus contorta trees.

\begin{tabular}{cccccc}
\hline \multirow{2}{*}{$\begin{array}{c}\text { Percentage of } \\
\text { circumference } \\
\text { barked }\end{array}$} & \multicolumn{2}{c}{ Fresh injuries } & & \multicolumn{2}{c}{$\begin{array}{c}\text { Prior year } \\
\text { injuries }\end{array}$} \\
\cline { 2 - 3 } \cline { 5 - 6 } & $\mathrm{N}$ & $\%$ & & $\mathrm{~N}$ & $\%$ \\
\hline $0-25$ & 31 & 32 & & 0 & 0 \\
$26-50$ & 25 & 26 & & 3 & 25 \\
$51-75$ & 22 & 23 & & 3 & 25 \\
$76-100$ & 18 & 19 & & 6 & 50 \\
\hline
\end{tabular}

$\mathrm{cm}^{2}$ to complete stripping of bark up to $1.8 \mathrm{~m}$ above the ground. About one-third of the 96 freshly damaged trees had bark stripped from $<25 \%$ of their circumference, and nearly onefifth showed bark removal of $>75 \%$ of the circumference (Table 2). Damage older than the current year was less conspicuous and may be disproportionately represented by larger scars. The incidence of sapwood feeding in the study area appeared to be greater in the current year than in the preceding years (Table 2). However, no differences could be detected between the size of trees damaged $(p=0.37)$ nor in the height of damage $(p=0.42)$ on freshly injured trees compared to those damaged in previous years.

The probable fate of freshly damaged trees was indicated by the condition of trees damaged in prior years: the six trees that had 26 to $75 \%$ bark removed were still alive, whereas the six trees with $>75 \%$ bark removal had all died. Examination of damaged trees indicated that the bear initially separated the bark near ground level (only 3 injuries originated higher than $15 \mathrm{~cm}$ above the ground) and then stripped upwards, usually leaving strips of bark attached at the top of the injury. In all cases the lowest point of damage was $\leq 41 \mathrm{~cm}$ of ground line. Most exposed wood was extensively marked with grooves made with incisors.

Analysis of increment cores indicated that the bears were feeding on young, vigorously growing trees. Cores from damaged trees averaged almost 35 annual rings (Table 1) and showed a mean annual diameter increment of $8.1 \mathrm{~mm}$ for the preceding $10 \mathrm{yr}$. Although cores were not obtained from unaffected lodgepole pine or other species, the general appearance of the forest stand suggested that these data were representative of all trees present.

\section{DISCUSSION}

The factors related to $U$. americanus feeding on sapwood and their selection of trees for such 
feeding are not clearly understood. Speculation that it is a response to food shortage (Resner 1953, Levin 1954, Lauckhart 1955) is not consistent with the observations of Tisch (1961), who noted that herbaceous forage was available at the time bears were feeding on trees. Potential factors influencing preference by $U$. americanus include physical properties of the bark (Lutz 1951, Levin 1954) and chemical composition of the sapwood (Radwan 1969). Similarly, B. Kimball (Denver Wildlife Research Center, unpubl. data) identified physical characteristics of the trees, carbohydrate content of the sapwood, and terpenoid content of the sapwood as factors influencing the extent of feeding on P. menziesii.

Selection of $P$. contorta by $U$. americanus has been noted in several interior forests, although relative degree of preference has varied among sites. Our observation of apparent preference for $P$. contorta over $P$. ponderosa and A. lasiocarpa is consistent with observations from eastern Washington (Poelker and Hartwell 1973) and northwestern Montana (Mason and Adams 1989).

Regardless of the causes, however, the occurrence of bark damage by bears can have important implications for forest management. Judging from the fate of trees with old injuries, $18(19 \%)$ of the 96 freshly stripped trees would be expected to die. Even with localized damage, if this rate of attrition were to continue for several years or expand into adjacent habitat, a considerable loss in timber production would result. Feeding was generally in open stands having high growth potential. Thus, injury was sustained by dominants that would continue to grow for eventual harvest.

Schmidt and Gourley (1992) summarized advantages and disadvantages of bear damage control strategies. They suggested that the best approach might be a combination of direct control of bear numbers and adjustments in silvicultural practices. In forest stands such as the one we studied where damage is light to moderate, it might be advisable to delay thinning until the damage subsides, since most black bear damage occurs in stands $<40 \mathrm{yr}$ old (Levin 1954, Lauckhart 1956, Glover 1955, Maser 1967).

\section{ACKNOWLEDGMENTS}

Assistance of Donald L. Rowe and Leland G. Klukkert, Deschutes National Forest, and James W. Bar- rett, Pacific Northwest Forest and Range Experiment Station, is gratefully acknowledged.

\section{LITERATURE CITED}

ChILdS TW, WORTHINGTON NP. 1955. Bear damage to young Douglas-fir. Portland, OR: USDA For Serv. Res Note Nr 113. 4 pages.

CONTOR R. 1957. Destructive sweet tooth. Yellowstone Nat Notes 3:7.

GLOVER FA. 1955. Black bear damage to redwood reproduction. J Wildl Manage 19:437-443.

HARTWELL HD. 1973. A survey of tree debarking by black bear in Capitol Forest. Olympia, WA: Wash Dept Nat Resour. DNR Notes 7:1-7.

JONKEL CJ, COWAN IM. 1971. The black bear in the spruce-fir forest. Wildl Monogr 27:1-57.

LAUCKHART JB. 1956. The effect of logging old growth timber on bear. Proc Soc Am For 1955: 123-130.

LEVIN OR. 1954. The South Olympic tree farm. J For 52:243-249.

LUTZ HJ. 1951. Damage to trees by black bears in Alaska. J For 49:522-523.

MASER C. 1967. Black bear damage to Douglas-fir in Oregon. Murrelet 48:34-38.

MASON AC, ADAMS DL. 1989. Black bear damage to thinned timber stands in northwest Montana. West J Appl For 4:10-13.

MOLNAR AC, MCMINN RG. 1960. The origin of basal scars in the B.C. interior white pine type. For Chron 36:50-60.

POELKER RJ, HARTWELl HD. 1973. Black Bear of Washington. Olympia, WA: Wash State Game Dept. Biol Bull 14. 180 pages.

RADWAN MA. 1969. Chemical composition of the sapwood of four tree species in relation to feeding by the black bear. For Sci 15:11-15.

RESNER OL. 1953. Damage to conifers by bear. Proc. West Assoc State Game Fish Comm 33:109-111.

SCHMIDT WC, GOURLEY M. 1992. Black bear. In: Black HC, technical editor. Silvicultural Approaches to Animal Damage Management in Pacific Northwest Forests. Portland, OR: USDA For Serv. Gen Tech Rep PNW-GTR-287. p 309-331.

TISCH EL. 1961. Seasonal food habits of the black bear in the Whitefish Range of northwestern Montana [thesis]. Missoula: Montana State Univ. $108 \mathrm{p}$.

VOLLAND LA. 1976. Plant communities of the central Oregon pumice zone. Portland, OR: USDA For Serv Pac Northwest Reg. R-6 Area Guide 4-2. $110 \mathrm{p}$.

ZEEDYK WD. 1957. Why do bears girdle balsam fir in Maine? J For 55:731-732.

Submitted 27 July 1994; accepted 21 April 1995. Corresponding editor: K. B. Aubry 